\title{
CORROSION RESISTANCE OF CrAIVN COATINGS DEPOSITED ON PCrNi3Mo STEEL SURFACES WITH REACTIVE MAGNETRON SPUTTERING
}

\author{
KOROZIJSKA ODPORNOST CrAIVN PREVLEK, NANEŠENIH NA \\ POVRŠINO JEKLA PCrNi3Mo Z REAKTIVNIM MAGNETRONSKIM \\ NAPRŠEVANJEM
}

\author{
Hao Jin ${ }^{1,2}$, De-Yuan Li², Hai-Jing Sun³ ${ }^{3}$ Lei Wang ${ }^{3}$, Ce-An Guo', Gang Zhang ${ }^{4}$ \\ ${ }^{1}$ Shenyang Ligong University, School of Equipment Engineering, no. 6 Nanping Central Road, Hunnan New District, \\ Shenyang City, Liaoning Province, 110159, China \\ ${ }^{2}$ Shenyang University of Technology, School of Material Science and Engineering, no. 111 Shenliao West Road, \\ Economic \& Technological Development Zone, Shenyang City, Liaoning Province, 110870, China \\ ${ }^{3}$ Shenyang Ligong University, School of Environmental and Chemical Engineering, no. 6 Nanping Central Road, \\ Hunnan New District, Shenyang City, Liaoning Province, 110159, China \\ ${ }^{4}$ Shenyang Ligong University, School of Material Science and Engineering, no. 6 Nanping Central Road, Hunnan New District, \\ Shenyang City, Liaoning Province, 110159, China \\ 104310@163.com
}

Prejem rokopisa - received: 2017-12-07; sprejem za objavo - accepted for publication: 2018-04-16

doi:10.17222/mit.2017.210

\begin{abstract}
CrAlN and CrAlVN coatings were deposited on the surfaces of PCrNi3Mo steel substrates using reactive magnetron sputtering. The surface and cross-sectional morphology, hardness and elastic modulus, and crystalline-phase structure of the coatings were characterized with scanning electron microscopy, nano-indentation and X-ray diffraction, respectively. Electrochemical testing was employed for analyzing the corrosion resistance of the uncoated steel substrate and the substrates coated with the two protective materials. The results show that the average grain size of the CrAlVN coating is greater than that of the CrAlN coating, and the hardness and elastic modulus of the CrAlVN coating (24.98 GPa and $336.02 \mathrm{GPa}$, respectively) are significantly greater than those of the CrAlN coating (23.91 GPa and $316.2 \mathrm{GPa}$, respectively). The corrosion current densities of the CrAlN and CrAlVN coated substrates are greater than that of the uncoated PCrNi3Mo steel by factors of about 4 and 100, respectively. The electrochemical-reaction resistances of the CrAIN and CrAlVN coated substrates are greater than that of the uncoated steel by factors of about 13 and 25 , respectively. While both coatings provided a substantially improved corrosion resistance, the CrAlVN coating performed better.
\end{abstract}

Keywords: magnetron sputtering, CrAlN coating, CrAlVN coating, corrosion resistance

Avtorji prispevka so CrAlN in CrAlVN prevleke nanašali na površino vzorcev iz PCrNi3Mo jekla s pomočjo reaktivnega magnetronskega naprševanja. Karakterizacijo površine in preseka vzorcev, morfologijo, trdoto, elastični modul in strukturo kristaliničnih faz prevlek so izvedli z vrstičnim elektronskim mikroskopom, nano-indenterjem (merilnikom trdote $\mathrm{z}$ vtiskovanjem trna nano velikosti) in rentgensko difrakcijo. Elektrokemijske preiskave so izvedli zato, da bi analizirali korozijsko odpornost vzorcev jekla s prevlekama v primerjavi z neprevlečenim materialom. Rezultati so pokazali, da je povprečna velikost kristalnih zrn CrAlVN prevleke večja kot CrAlN prevleke. Trdota in elastični modul CrAlVN prevleke (24,98 GPa oz. 336,02 GPa) sta precej večja od trdote in elastičnega modula CrAlN prevleke (23,91 GPa oz. 316,2 GPa). Korozijski gostoti toka vzorcev z obema prevlekama sta večji kot je pri neprevlečenem PCrNi3Mo jeklu za faktor približno 4 oziroma 100. Elektrokemična reakcijska odpornost vzorcev, prevlečenih s CrAlN in CrAlVN, je v primerjavi z neprevlečenimi vzorci večja za faktorje približno 13 oziroma 25 . Ugotavljajo, da obe prevleki sicer zagotavljata znatno izboljšanje korozijske obstojnosti jekla, vendar je CrAlVN prevleka boljša.

Ključne beseda: magnetronsko naprševanje, CrAlN prevleka, CrAlVN prevleka, odpornost proti koroziji

\section{INTRODUCTION}

The cost of artillery barrels is about $30-40 \%$ of the overall price of artillery tractors. The ablation and wear of the inner gun barrel is the primary cause of the gun-barrel failure. Consequently, a number of inner-barrel treatments, such as laser treatment, ${ }^{1-2}$ laser quenching and Cr-composite finishing ${ }^{3-5}$ were developed to improve the service life of gun barrels by controlling their ablation. Moreover, the deposition of anti-ablative coatings on the inner barrel surface has been a strong focus of research, and has included numerous coatings and meth- ods, such as electroplated $\mathrm{Cr}^{6}$ sputtered $\mathrm{Ta}^{7-9}$ and laser Cr-composite processing, ${ }^{10,11}$ in addition to the other coatings applied, e.g., plasma surfacing ${ }^{12}$ and chemical vapor deposition. ${ }^{13}$ At present, electroplated $\mathrm{Cr}$ is the most widely adopted anti-ablative coating for improving the service life of artillery barrels. However, the above listed methods have so far failed to solve the problem of gun-barrel ablation effectively. Moreover, the range, firing frequency and internal projectile speed of artillery are constantly increasing, and the barrel ablation and wear are correspondingly increasing as well. Consequently, conventional $\mathrm{Cr}$ electroplating cannot meet the 
present and developing requirements for artillery-barrel lifetimes.

In addition to the ablation and wear of the inner gun barrels in the process of combat use, artillery in marine environments is subjected to corrosion during extended periods in a non-combat state because sea water is rich in chloride ions that lead to the local corrosion of metals. Corrosion of the inner surfaces of gun barrels greatly accelerates ablation during the service, which will correspondingly accelerate the process of barrel failure, resulting in greatly increased military expenses. Clearly, the efforts to improve the service life of gun barrels by controlling ablation must involve coatings with good corrosion resistance. In addition to these concerns, the waste liquid produced in the $\mathrm{Cr}$-electroplating process is a source of serious pollution problems. ${ }^{14}$ In these respects, $\mathrm{CrAlN}$, which has been applied as a functional material coating in various industrial fields, is an excellent candidate owing to its high hardness, excellent abrasion resistance, excellent toughness, and good corrosion resistance. ${ }^{15-20}$ In particular, the good corrosion resistance is provided by the active $\mathrm{Cr}$ element in the film, which forms a dense $\mathrm{Cr}_{2} \mathrm{O}_{3}$ surface-passivation layer.

In this paper, ternary CrAlN coatings were prepared on the surfaces of the $\mathrm{PCrNi} 3 \mathrm{Mo}$ steel using reactive magnetron sputtering. In addition, quaternary CrAlVN coatings were also prepared. The effects of doping with $\mathrm{V}$ on the structure and mechanical properties of the CrAlN coatings are discussed. The corrosion resistances of the uncoated PCrNi3Mo steel substrate and the substrates coated with the two protective materials were evaluated in a $3.5 \%$ of mass fractions of $\mathrm{NaCl}$ solution with polarization-curve testing and electrochemical impedance spectroscopy (EIS). This paper provides a good reference for future research regarding the service-life extension of artillery using CrAlN and CrAlVN coatings deposited on the inner surface of gun barrels with reactive magnetron sputtering.

\section{EXPERIMENTAL PART}

\subsection{Experimental materials}

The nominal chemical composition of the PCrNi3Mo steel substrates is given in Table 1. The substrates were subjected to wire cutting to produce samples with dimensions of $(15 \times 15 \times 3) \mathrm{mm}$. The samples were then machined using a surface grinder and, successively, polished with 400\#, 600\#, 800\#, 1000\#, 1500\#, and 2000\# SiC abrasive papers. The samples were then successively polished with W2.5, W1.5 and W0.5 grinding pastes. The samples were subsequently cleaned with acetone and alcohol for $10 \mathrm{~min}$ to remove oil from the surfaces and then dried for $30 \mathrm{~min}$ in the sputtering chamber. The sample pre-processing was conducted to increase the adhesion between the coating and the underlying steel substrate. ${ }^{21}$
Table 1: Nominal chemical composition of PCrNi3Mo steel (wt \%)

\begin{tabular}{|c|c|c|c|c|c|c|c|c|}
\hline $\mathrm{C}$ & $\mathrm{Mn}$ & $\mathrm{Si}$ & $\mathrm{Cr}$ & $\mathrm{Ni}$ & $\mathrm{Mo}$ & $\mathrm{V}$ & $\mathrm{S}$ & $\mathrm{P}$ \\
\hline 0.4 & 0.41 & 0.25 & 1.28 & 3.14 & 0.37 & 0.20 & 0.001 & 0.012 \\
\hline
\end{tabular}

\subsection{Experimental methods}

In the deposition experiments, $\mathrm{Cr}, \mathrm{Al}$ and $\mathrm{V}$ targets with a $99.95 \%$ purity were employed in a QHV-JGP400B II multi-target magnetron-sputtering unit at a pressure of $6.0 \times 10^{-5} \mathrm{~Pa}$. The rotational speed of the substrate was $80 \mathrm{~min}^{-1}$, the substrate temperature was $350{ }^{\circ} \mathrm{C}$, and the distance between the targets and substrate was $60 \mathrm{~mm}$. The Cr-target current was $0.2 \mathrm{~A}$, the $\mathrm{V}$-target current was $0.07 \mathrm{~A}$, and the Al-target power was $150 \mathrm{~W}$. The sputtering time was $1 \mathrm{~h}$ for both coatings. The hardness and elastic modulus of the coatings were tested with nano-indentation using a G200 nano-indenter. The surface, cross-sectional morphology, and composition of the coatings were investigated with scanning electron microscopy (SEM) and energy dispersive spectroscopy (EDS) using an SU8010 field emission scanning electron microscope and an attached spectrometer. The phase compositions of the coatings were determined with X-ray diffraction (XRD) using a SHIMADZU XRD-7000 diffractometer with the $\mathrm{Cu} K_{\alpha}$ source having a wavelength of $0.154056 \mathrm{~nm}$, a scanning diffraction angle in a range of $30-90^{\circ}$, a scanning step of $0.02 \%$, and a scanning speed of $3 \% \mathrm{~min}$. A CHI660A electrochemical tester was employed for analyzing the sample corrosion. Electrochemical testing was conducted using a three-electrode system where the saturated electrode (SCE) was used as the reference electrode, $3.5 \%$ $\mathrm{NaCl}$ was used as the auxiliary electrode, and the analysis medium and distilled water were used as the experimental medium. The cell temperature was maintained at $25 \pm 1{ }^{\circ} \mathrm{C}$ using a constant-temperature water bath. Prior to conducting voltammetry experiments, the working electrode was polarized at $-1 \mathrm{~V}$ for 2 min to remove any oxide layer previously formed in air. The scanning speed was $0.33 \mathrm{mV} / \mathrm{s}$. During the measurements of the constant potential-constant current (PG) transient response, the working electrode was polarized at a constant potential of $-0.05 \mathrm{~V}$ for $15 \mathrm{~min}$. When the electrode surfacepassivation current density attains a value of $I_{\mathrm{p}}$, the current is switched to constant current control (i.e., a current density set to $0.5 I_{\mathrm{p}}$ ). At the moment of conversion, the electrode potential is recorded when the current-density change on the surface of the working electrode is $-0.5 I_{\mathrm{p}}$.

\section{RESULTS AND DISCUSSION}

\subsection{Microstructures of the CrAlN and CrAlVN coat- ings}

The surface morphologies of the as-deposited CrAlN and CrAlVN coatings are shown by the SEM micrographs presented in Figures 1a and $\mathbf{1 b}$, respectively. We note that the CrAlN coating surface exhibits a typical 

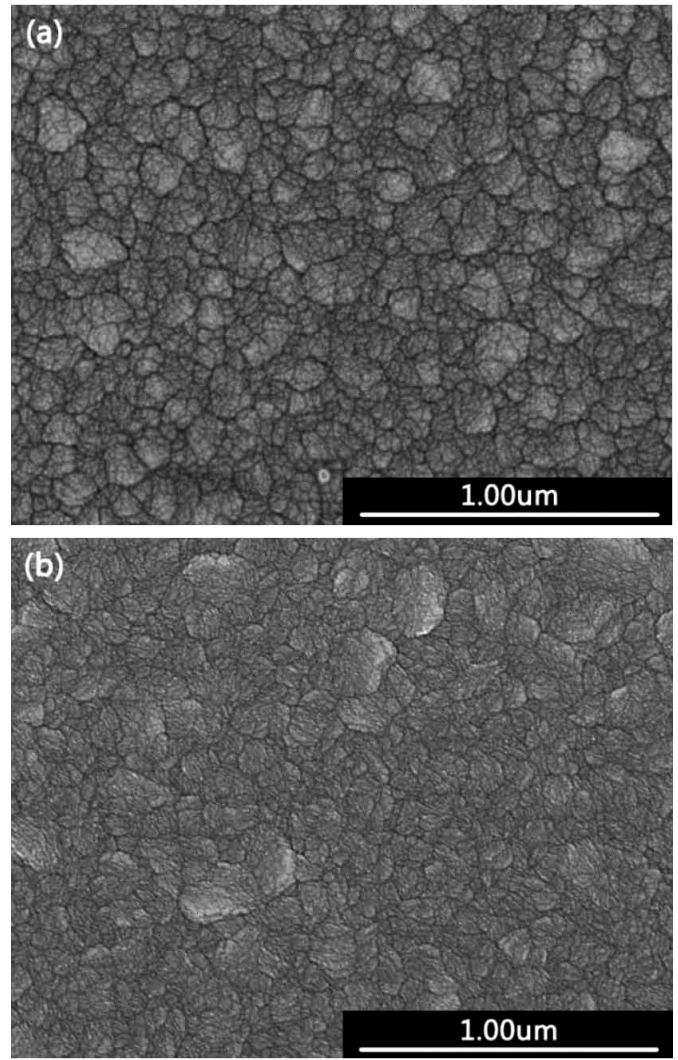

Figure 1: SEM micrographs representing the surface morphologies of: a) CrAlN and b) CrAlVN coatings

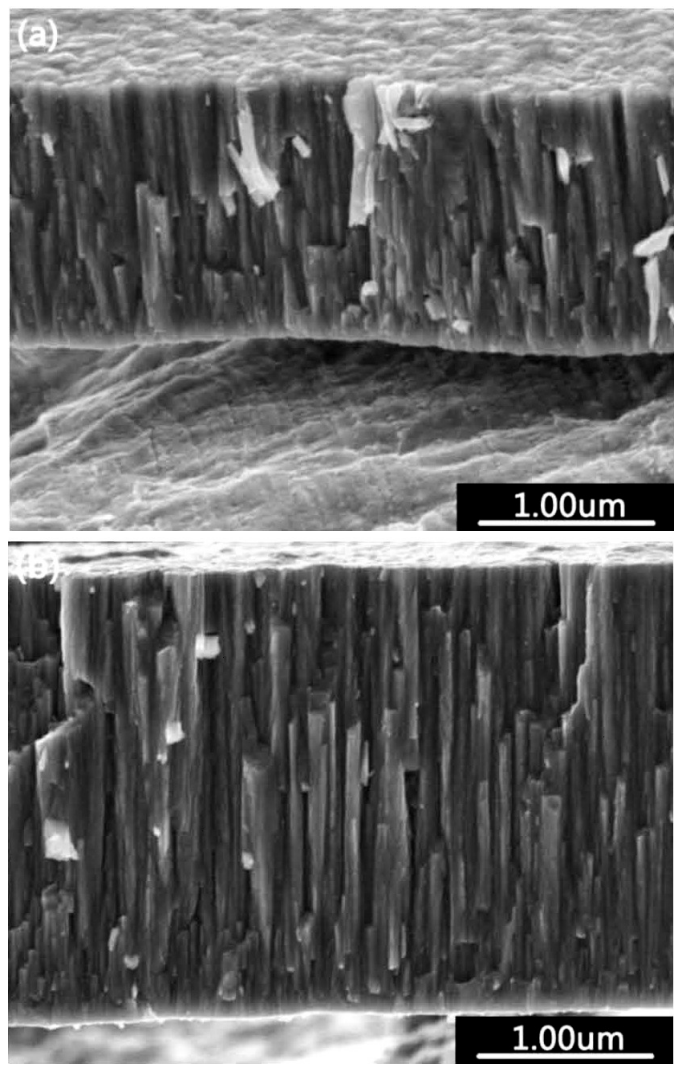

Figure 2: SEM micrographs representing the cross-sectional morphologies of: a) CrAlN and b) CrAlVN coatings cauliflower morphology indicative of an aggregation of fine, typically spherical particles into a collection of larger particles of varying sizes. The shapes of the large particles on the surface of the CrAlVN film are irregular and the particles are tightly bonded. The surface of the CrAlVN coating is flat and dense. The greater density may be due to the introduction of $\mathrm{V}$, which changed the formation of atomic pairs or the nature of the atomic group. The critical nuclei that form a stable size during the sputtering changed the surface morphology relative to that of the CrAlN coating.

Cross-sectional SEM micrographs of the as-deposited CrAlN and CrAlVN coatings are shown in Figure 2, which clearly reveals that both coatings are formed of a typical columnar polycrystalline structure. We note that the introduction of $\mathrm{V}$ increases the columnar crystal density of the CrAIVN coating as well as the tendency of the columnar crystals to become short-axis crystals. We applied Digimizer software to evaluate the average coating thickness based on five positions marked at the junction of the fracture surface and the coating base. The results show that the average thickness of the CrAlN coating was $1.51 \mu \mathrm{m}$ and that of the CrAlVN coating was $2.57 \mu \mathrm{m}$. Therefore, the deposition rate was increased from $25.17 \mathrm{~nm} / \mathrm{min}$ for the CrAlN coating to $42.83 \mathrm{~nm} / \mathrm{min}$ for the CrAlVN coating, which represents an increase of $17.68 \%$.

The XRD patterns of the as-deposited CrAlN and CrAlVN coatings reveal that both CrAlN and CrAlVN coatings have a single-phase cubic structure ( $\mathrm{NaCl}$ type) (Figure 3). No AlN can be observed in the hep wurtzite structure after the deposition. V tends to form a solid solution in the CrAlN-based lattice rather than forming an individual VN phase. Further, it can also be seen that the addition of V significantly increases the (200)/(111) diffraction-peak intensity ratio, which is indicative of the preferred growth orientation related to the surface energy and strain energy in the grain-growth process. ${ }^{22-24}$ Coatings with a face-centered cubic (fcc) structure tend to grow in the direction of low strain energy to minimize

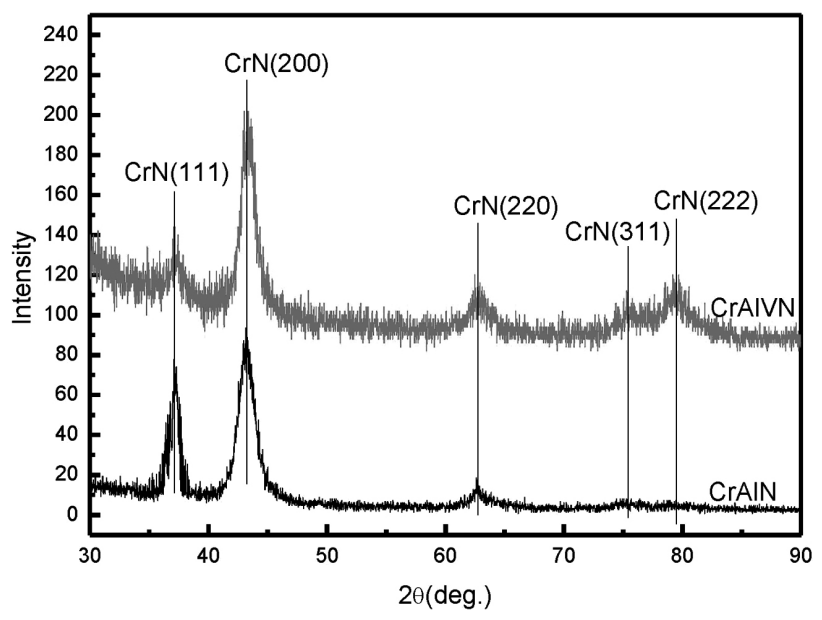

Figure 3: XRD patterns of the two as-deposited coatings 
the increase in the stress and strain during the growth. The XRD results show that the growth of the coating along the (111) direction is suppressed by the addition of $\mathrm{V}$. This indicates that the stress and strain in the interior of the coating are not determined in the preferred direction. Thus, the CrAlVN coating preferentially grows along the (200) direction, which has the lowest surface energy, and forms a fine-grain structure.

\subsection{Hardness and elastic moduli of the CrAlN and CrAlVN coatings}

The hardness and elastic modulus of the uncoated PCrNi3Mo steel substrate obtained with nano-indentation were $5.57 \mathrm{GPa}$ and $258 \mathrm{GPa}$, respectively. The hardness of the CrAlN coating in the as-deposited state was $23.91 \mathrm{GPa}$. As a consequence of the solid-solution strengthening, the as-deposited CrAlVN coating obtained a higher hardness of $24.98 \mathrm{GPa}$. On the other hand, the introduction of the stronger $\mathrm{V}-\mathrm{N}$ bond as well as the obstructed dislocation movement from the solid solution, reveal a higher elastic modulus of $336 \mathrm{GPa}$ for CrAlVN compared to $316.2 \mathrm{GPa}$ for CrAlN.

\subsection{Corrosion resistance of the CrAlN and CrAlVN coatings}

The polarization curves of the uncoated PCrNi3Mo steel substrate and the ubstrates coated with CrAlN and CrAlVN films are shown in Figure 4. It can be seen from the figure that the open-circuit potentials of the uncoated steel substrate and CrAlN and CrAlVN coated substrates (relative to the SCE) are $-0.585 \mathrm{~V},-0.382 \mathrm{~V}$ and $-0.211 \mathrm{~V}$, respectively. The coatings obviously provide different degrees of improvement in the corrosion potential of the steel. From a thermodynamic point of view, an increasing corrosion potential decreases the likelihood of an electrochemical reaction. These results indicate that both CrAlN and CrAlVN coatings increase

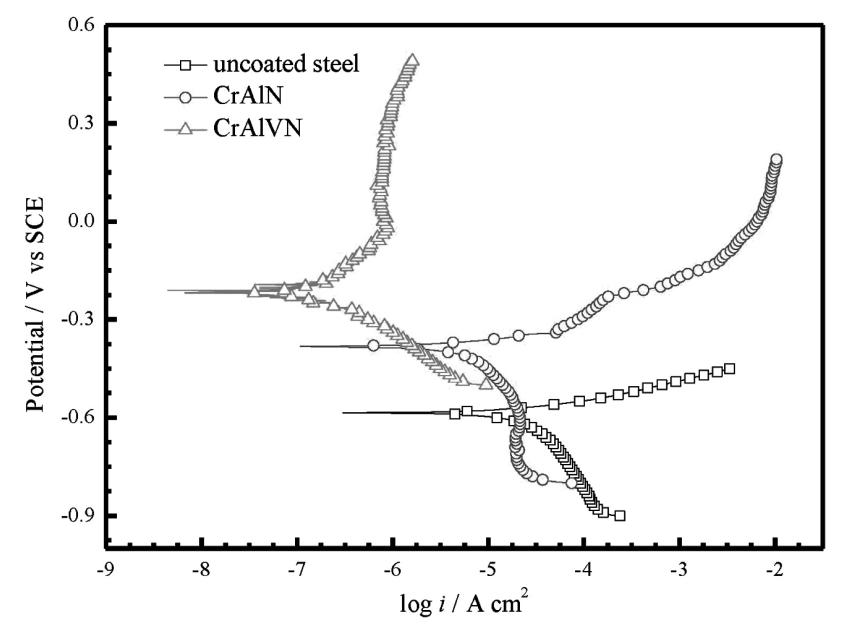

Figure 4: Potentiodynamic polarization curves of the PCrNi3Mo steel substrate and the CrAlN and CrAlVN coated substrates in a $3.5 \%$ $\mathrm{NaCl}$ solution the corrosion resistance of the steel substrate, but only the CrAlVN coating provides superior corrosion resistance.

We note that the PCrNi3Mo steel exhibited active dissolution in the $3.5 \% \mathrm{NaCl}$ solution. The anodic-polarization current density of the steel increased very rapidly with an increasing polarization potential, while the anodic-polarization current density of the CrAlN coated substrate increased more slowly, indicating an increased corrosion resistance. In contrast, the polarization current density of the CrAlVN coated substrate increased very slowly with the increasing polarization potential, and exhibited little change after the transient anodic dissolution of the anodic-polarized region above the corrosion potential. These characteristics are representative of passivation. The passivation current density was about $1 \mu \mathrm{A} / \mathrm{cm}^{2}$. In addition, the cathodicpolarization current densities of the CrAlN and CrAlVN coated substrates were lower than that of the uncoated steel substrate, indicating that the coatings suppressed the cathode reaction of the material. Clearly, the inhibition of the CrAlVN coating is more significant. In a neutral solution, the cathode reaction of the uncoated steel substrate is mainly the reduction of the oxygen dissolved in water, which can be expressed as

$$
2 \mathrm{H}_{2} \mathrm{O}+2 \mathrm{O}_{2}+4 \mathrm{e}^{-}=4 \mathrm{OH}^{-}
$$

The data obtained by fitting the polarization curves of the three samples using CorrView are listed in Table 2. Here, $E_{\text {corr }}$ is the corrosion potential, $i_{\text {corr }}$ is the corrosion current density, $b_{\mathrm{c}}$ is the cathode tangent slope, and $b_{\mathrm{a}}$ is the anode tangent slope. Generally, the self-corrosion potential of a material is more negative, and the material tends to be more aggressive. However, once the material enters the corroded state, $i_{\text {corr }}$ becomes an important index for the evaluation of the corrosion resistance of the material where, with the increasing $i_{\text {corr }}$, the corrosion rate decreases, and, correspondingly, the corrosion resistance increases. As can be seen from the table, the value of $i_{\text {corr }}$ for the uncoated PCrNi3Mo steel substrate in the $3.5 \% \mathrm{NaCl}$ solution was reduced from 6.55 $\mu \mathrm{A} / \mathrm{cm}^{2}$ to $1.66 \mu \mathrm{A} / \mathrm{cm}^{2}$ and $0.066 \mu \mathrm{A} / \mathrm{cm}^{2}$ for the CrAlN and CrAlVN coated substrates, respectively. These values represent the reductions in $i_{\text {corr }}$ by factors of about 4 and 100, respectively. These results further indicate that the coatings improve the corrosion resistance of the steel substrate, and that the corrosion resistance of the CrAlVN coated substrate is superior.

Table 2: Results of fitting to the potentiodynamic curves from Figure 4

\begin{tabular}{|c|c|c|c|c|}
\hline & $\begin{array}{c}E_{\text {corr }}(\mathrm{V} \text { vs. } \\
\text { SCE })\end{array}$ & $\begin{array}{c}i_{\text {corr }} \\
\left(\mu \mathrm{A} / \mathrm{cm}^{2}\right)\end{array}$ & $\begin{array}{c}b_{\mathrm{c}}(\mathrm{mV} / \\
\text { decade })\end{array}$ & $\begin{array}{c}b_{\mathrm{a}}(\mathrm{mV} / \\
\text { decade })\end{array}$ \\
\hline Steel substrate & -0.585 & 6.55 & 3.48 & 18.18 \\
\hline CrAlN coating & -0.382 & 1.66 & 3.29 & 16.81 \\
\hline CrAlVN coating & -0.211 & 0.066 & 6.14 & 4.04 \\
\hline
\end{tabular}

As demonstrated with the results of electrochemical testing, the PCrNi3Mo steel substrates with CrAlN and 

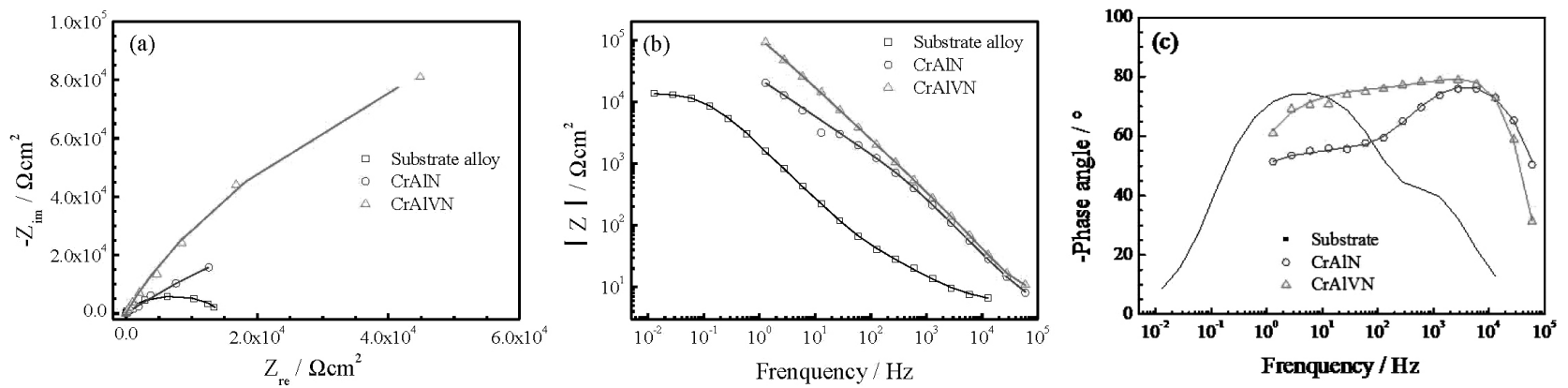

Figure 5: Electrochemical-impedance-spectroscopy results for the uncoated PCrNi3Mo steel substrate and CrAlN and CrAlVN coated substrates: a) Nyquist plots, b) Bode plots, c) phase angle versus frequency

CrAlVN coatings have good corrosion resistance in the $3.5 \% \mathrm{NaCl}$ solution. In addition, as discussed in Subsections 3.1-3.3, the introduction of V provided for a refined microstructure of the coating, leading to finer, more uniform and dense-grain clusters than those of the CrAlN coating, also enhancing its corrosion resistance. ${ }^{25}$

The electrochemical impedance spectra for the uncoated PCrNi3Mo steel substrate and $\mathrm{CrAlN}$ and CrAlVN coated substrates are shown in Figures 5a to 5c, which represent the Nyquist plots, the Bode plots and the phase angles versus frequency, respectively. The radius of the impedance arc shown in the Nyquist plot (Figure 5a) is representative of the corrosion resistance of the material where the corrosion resistance increases with the increasing radius. These results therefore verify the results derived from the polarization curves, indicating that the corrosion resistance of the steel substrate in the $3.5 \% \mathrm{NaCl}$ solution is poor, while that of the CrAlN coated substrate is considerably better, and that of the CrAlVN coated substrate is even better. It can be seen from the Bode plots (Figure 5b) that low-frequency impedances (i.e., the absolute value of the impedance $|\mathrm{Z}|)$ have the same order of magnitude, which again demonstrates that the CrAlN coating and, particularly, the CrAlVN coating improve the corrosion resistance of the PCrNi3Mo steel in the $3.5 \% \mathrm{NaCl}$ solution.

The electrochemical impedance spectra for the three samples were analyzed using the equivalent circuit illustrated in Figure 6. Here, $R_{\mathrm{s}}$ is the resistor that represents the solution resistance between the reference electrode and the sample to be measured; $R_{\mathrm{po}}$ is the resistor that represents the layer resistance associated with the barrier effect of the coating, and also the protective effect of the corrosion product on the uncoated steel substrate; $C P E_{\mathrm{po}}$ is the capacitor that represents the non-ideal capacitance associated with the coating; $C P E_{\mathrm{dl}}$ is the capacitor that represents the non-ideal double-layer capacitance associated with the metal-substrate reaction under the coating; and $R_{\mathrm{ct}}$ is the resistor that represents the metal-coating interface reaction impedance. Using pure capacitance, it is difficult to evaluate the actual electrochemical process, particularly for solid-electrode materials. Therefore, the phase angle of the original is commonly used to replace the non-ideal capacitor. In addition, CPE is used to represent the deviation of the actual capacitance, which can be given as follows:

$$
Z_{\mathrm{CPE}}=\frac{1}{Y_{0}(j \omega)^{n}}
$$

Here, $Y_{0}$ is the specific admittance $\left(s^{\mathrm{n}} / \Omega \cdot \mathrm{cm}^{2}\right) ; \omega$ is the angular frequency $(\mathrm{rad} / \mathrm{s})$; and $n$ is the dispersion index, which indicates the degree of deviation from the pure capacitance where $n=1$ represents the ideal capacitance, and $n=0$ represents the pure resistance. The value of $n$ is generally close to 1 , and represents the non-ideal capacitance characteristics of the metal-coating interface.

The AC impedance data for the uncoated PCrNi3Mo steel substrate and CrAlN and CrAlVN coated substrates were fitted using the ZView software according to the equivalent circuit shown in Figure 6, and the results are listed in Table 3. The analysis of the fitted results reveals details regarding the mechanism of the corrosion resistance. The $R_{\mathrm{po}}$ values obtained for the three materials are shown in Figure 7. Because the PCrNi3Mo steel substrate has a much lower $\mathrm{Cr}$ content $(1.28 \%$ of mass fractions) than the coating materials, a weak $\mathrm{Cr}_{2} \mathrm{O}_{3}$ passivation layer is formed on its surface. Therefore, the reported active-dissolution reaction mechanism occurring in a salt solution containing corrosive $\mathrm{Cl}$ ions ${ }^{26}$ may be similar to that of the general carbon steel in an environment rich in $\mathrm{Cl}$ ions. ${ }^{27}$ This forms loose corrosion products on the surface that lack a reasonable protective effect in the corrosive $\mathrm{Cl}$-ion environment, which is reflected by a very low value of $38.91 \Omega / \mathrm{cm}^{2}$ obtained for $R_{\mathrm{po}}$. In contrast, the value of $R_{\mathrm{po}}$ increased to 1333

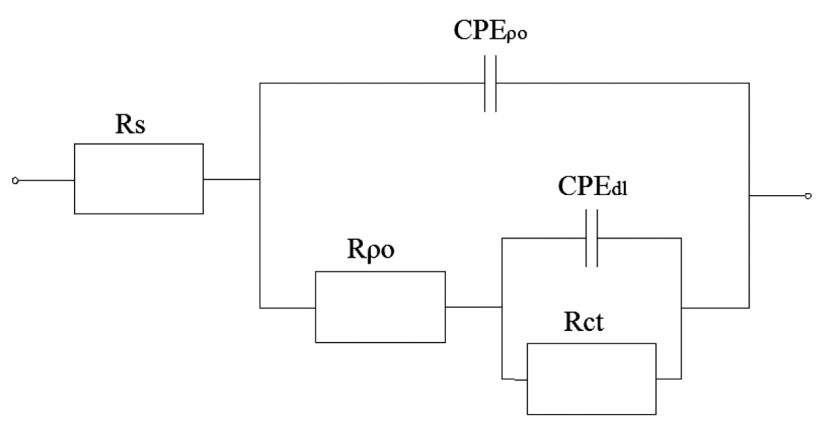

Figure 6: Equivalent electrical-circuit model 
H. JIN et al.: CORROSION RESISTANCE OF CrAIVN COATINGS DEPOSITED ON PCrNi3Mo STEEL ...

Table 3: Results of fitting the AC impedance data for the uncoated PCrNi3Mo steel substrate and CrAlN and CrAlVN coated substrates to the equivalent electrical-circuit model from Figure 6

\begin{tabular}{|c|c|c|c|c|c|c|c|}
\hline \multirow{2}{*}{ Sample } & \multirow{2}{*}{$\begin{array}{c}R_{\mathrm{s}} \\
\left(\Omega / \mathrm{cm}^{2}\right)\end{array}$} & \multirow{2}{*}{$\begin{array}{c}R_{\mathrm{po}} \\
\left(\Omega / \mathrm{cm}^{2}\right)\end{array}$} & \multicolumn{2}{|c|}{$C P E_{\mathrm{po}}$} & \multirow{2}{*}{$R_{\mathrm{ct}}\left(\Omega / \mathrm{cm}^{2}\right)$} & \multicolumn{2}{|c|}{$C P E_{\mathrm{dl}}$} \\
\hline & & & $Y_{0}\left(\mathrm{~s}^{\mathrm{n}} / \Omega \cdot \mathrm{cm}^{2}\right)$ & $n$ & & $Y_{0}\left(\mathrm{~s}^{\mathrm{n}} / \Omega \cdot \mathrm{cm}^{2}\right)$ & $n$ \\
\hline Steel substrate & 6.064 & 38.91 & $4.577 \times 10^{-5}$ & 0.84345 & 14308 & $5.272 \times 10^{-5}$ & 0.89505 \\
\hline CrAlN & 4.294 & 1333 & $1.144 \times 10^{-6}$ & 0.91892 & 191150 & $1.185 \times 10^{-5}$ & 0.59965 \\
\hline CrAlVN & 11.32 & 4532 & $5.788 \times 10^{-9}$ & 0.976 & 353850 & $2.666 \times 10^{-7}$ & 0.83379 \\
\hline
\end{tabular}

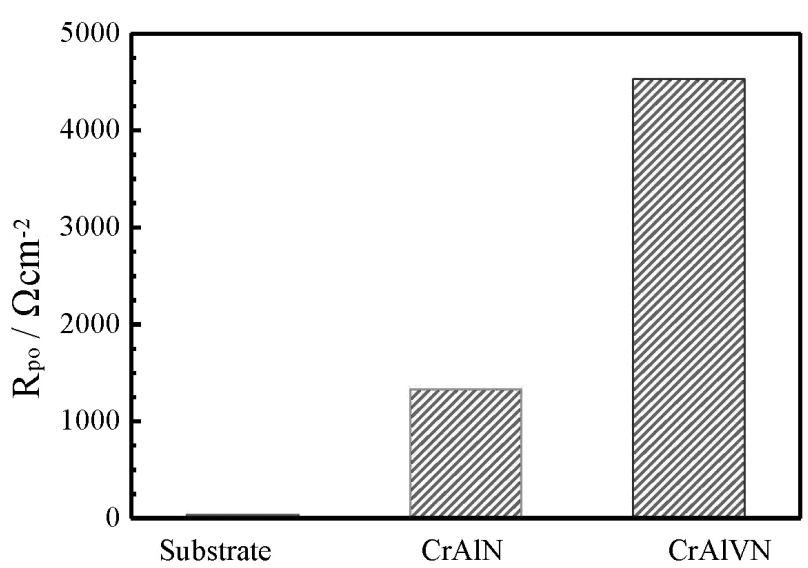

Figure 7: Values of $R_{\text {po }}$ for the uncoated PCrNi3Mo steel substrate and CrAlN and CrAlVN coated substrates

$\Omega / \mathrm{cm}^{2}$ after the steel substrate was coated with the CrAlN film, and further increased to $4532 \Omega / \mathrm{cm}^{2}$ after the coating with the CrAlVN film. This shows that both coatings provided a good barrier effect, while the CrAlVN coating was superior.

The $R_{\mathrm{ct}}$ values obtained for the three materials are shown in Figure 8. Based on the definition of $R_{\mathrm{ct}}$, larger values of $R_{\mathrm{ct}}$ represent a greater resistance to electrochemical reactions, making them less likely. As can be seen from Table 3, the value of $R_{\mathrm{ct}}$ increased from $14308 \Omega / \mathrm{cm}^{2}$ for the uncoated PCrNi3Mo substrate material to $191,150 \Omega \mathrm{cm}^{-2}$ after the coating with a layer of CrAlN, and further increased to $353850 \Omega / \mathrm{cm}^{2}$ after the coating with a layer of CrAlVN. These figures represent increases in the value of $R_{\mathrm{ct}}$ for the uncoated substrate by factors of 13 and 25 , respectively. The characterization results and discussion clearly demonstrate that the improved protective effect of the CrAlVN coating is related to its more uniform and dense microstructure.

\section{CONCLUSIONS}

This research investigated the preparation of CrAlN and CrAlVN coatings on the surfaces of PCrNi3Mo steel using reactive magnetron sputtering. The effects of doping with $\mathrm{V}$ on the structure and mechanical properties of the CrAlN coatings were discussed. The corrosion resistance of the uncoated $\mathrm{PCrNi3Mo}$ steel substrate and the substrates coated with the two protective materials was evaluated in a $3.5 \%$ of mass fractions of $\mathrm{NaCl}$

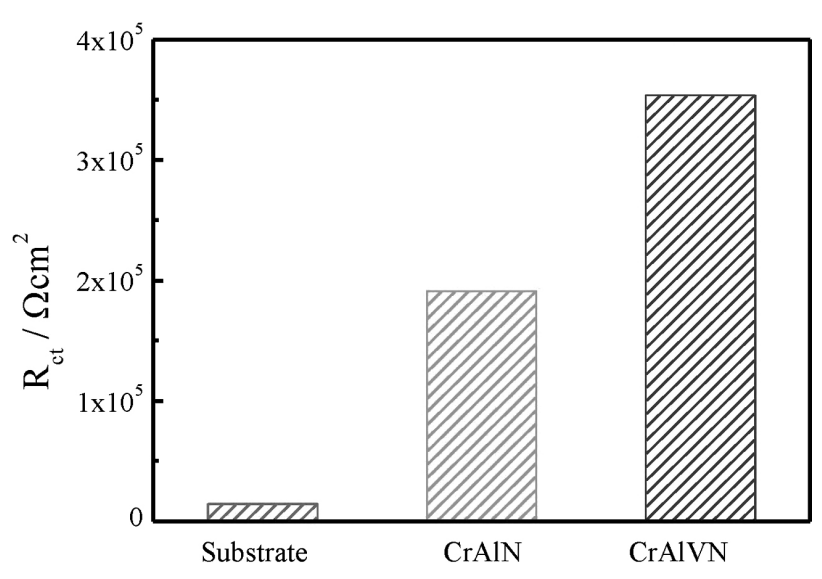

Figure 8: Values of $R_{\mathrm{ct}}$ for the uncoated PCrNi3Mo steel substrate and CrAlN and CrAlVN coated substrates

solution using polarization-curve testing and EIS. Based on the results, the following conclusions can be drawn:

1) The hardness and elastic modulus of the CrAlN coated steel substrates increased from 23.91 GPa and $316.2 \mathrm{GPa}$ to $24.98 \mathrm{GPa}$ and $336 \mathrm{GPa}$, respectively, owing to the introduction of $\mathrm{V}$ into the CrAlN coating.

2) The PCrNi3Mo steel was dissolved in the $3.5 \%$ $\mathrm{NaCl}$ solution, and the corrosion products on its surface demonstrated no protective effect.

3) The corrosion resistance of the PCrNi3Mo steel substrates was enhanced by coating them with CrAlN and CrAlVN films. The CrAlVN coating demonstrated a superior protective effect, and a more advanced passivation phenomenon. The cathodic reaction of the PCrNi3Mo steel substrate was suppressed with the CrAlN and CrAlVN coatings.

4) The excellent corrosion protection of the CrAlVN coating results from its uniform and dense microstructure.

\section{Acknowledgment}

This work was supported by the Shenyang Ligong University Open Fund of Key Laboratory, Liaoning Province, China (4771004kfs42).

\section{REFERENCES}

${ }^{1}$ Y. C. Chen, Q. Z. Song, New technologies to extend the erosion life of gun barrel, Acta Armamentrarii, 27 (2006) 2, 330-334, doi:10.3321/j.issn:1000-1093.2006.02.031 
${ }^{2}$ Y. Wang, Z. Q. Deng, L. T. Qi, An experimental study on the laser hardening of artillery bores, Acta Armamentrarii, 24 (2003) 4, 476-478, doi:10.3321/j.issn:1000-1093.2003.04.011

${ }^{3}$ G. X. Zhang, K. Zhang, G. N. Chen, Interfacial corrosion and spallation of Cr-plated coating on a gun barrel steel substrate pre-treated by laser spiral quenching, Corrosion Science and Protection Technology, 18 (2006) 6, 418-421, doi:10.3969/ j.issn.1002-6495.2006.06.007

${ }^{4}$ H. X. Li, G. N. Chen, K. Zhang, Degradation of microstructure of duplex electroplated chromium layers in gun barrels, Transactions of Materials and Treatment, 28 (2007) 4, 111-115, doi:10.3969/j.issn.1009-6264.2007.04.025

${ }^{5}$ G. X. Zhang, G. N. Chen, K. Zhang, Mechanical mechanism study on prolonging life of chromium-plated gun bore through laser discrete pretreatment, Acta Armamentrarii, 27 (2006) 6, 978-983, doi:10.3321/j.issn:1000-1093.2006.06.005

${ }^{6}$ L. Wang, D. S. Kim, K. S. Nam, Microstructure of electroplated hard chromium coatings after plasma nitrocarburizing, Sufr. Coat. Tech., 190 (2005) 2-3, 151-154, doi:10.1016 / j.surfcoat. 2004.08.213

${ }^{7} \mathrm{C}$. Warnecke, Method of coating an inner surface of a weapon barrel, US, 2002, US6352740

${ }^{8}$ D. W. Matson, E. D. McClanahan, J. P. Rice, Effect of sputtering parameters on Ta coatings for gun bore applications, Sufr. Coat. Tech., 133-134 (2000), 411-416, doi:10.1016/S0257-8972(00) 00967-1

${ }^{9}$ S. L. Lee, D. Windover, Phase, residual stress, and texture in triode-sputtered tantalum coatings on steel, Sufr. Coat. Tech., 108-109 (1998) 1, 65-72, doi:10.1016/S0257-8972(98)00666-5

${ }^{10}$ X. H. Li, K. Zhang, G. N. Chen, Characterization of a laser-discrete quenched steel substrate/chromium system by dissolving coatings, Sufr. Coat. Tech., 201 (2006) 6, 3709-3714, doi:10.1016/j.surfcoat. 2006.09.002

${ }^{11}$ R. S. Montgomery, Laser treatment of chromium plated steel, Wear, 56 (1979) 1, 155-166, doi:10.1016/0043-1648(79)90015-2

${ }^{12} \mathrm{C}$. Warnecke, Method of internally coating a weapon barrel by means of a laser beam, US, 2003, US6548125

${ }^{13}$ A. Victor, S. Andrew, Method for making a high temperature, high pressure, erosion and corrosion resistant composite structure, US, 1999, 5935351

${ }^{14}$ L. Gan, F. H. Tao, X. H. Lu, J. J. Tao, Research on barrel life prolongation, Journal of Gun Launch, 12 (2006) 3, 10-14, doi:10.3969/j.issn.1673-6524.2006.03.003

${ }^{15}$ L. Wang, G. Zhang, R. J. K. Wood, Fabrication of CrAlN nanocomposite films with high hardness and excellent anti-wear performance for gear application, Sufr. Coat. Tech., 204 (2010), 3517-3524, doi:10.1016/j.surfcoat.2010.04.014

${ }^{16}$ T. Polcar, A. Cavaleiro, High-temperature tribological properties of CrAlN, CrAlSiN and AlCrSiN coatings, Sufr. Coat. Tech., 206 (2011) 6, 1244-1251, doi:10.1016 / j.surfcoat. 2011.08.037

${ }^{17} \mathrm{~S}$. Ulrich, H. Holleck, J. Ye, Influence of low energy ion implantation on mechanical properties of magnetron sputtered metastable (Cr,Al)N thin films, Thin Solid Films, 437 (2003) 1-2, 164169 , doi:10.1016/S0040-6090(03)00595-9

${ }^{18}$ M. A. Baker, P. J. Kench, M. C. Joseph, The nanostructure and mechanical properties of PVD $\mathrm{CrCu}(\mathrm{N})$ coatings, Sufr. Coat. Tech., 162 (2003) 2-3, 222-227, doi:10.1016/S0257-8972(02)00571-6

${ }^{19}$ E. Lugscheider, K. Bobzin, K. Lackner, Deposition, characterization and machining performance of multilayer PVD coatings on cemented carbide cutting tools, Sufr. Coat. Tech., 163-164 (2003), 681-688, doi.org/10.1016/S0257-8972(02)00656-4

${ }^{20}$ I. Braceras, J. I. Onate, J. C. Sánchez, Magnetron sputtering of $\mathrm{Cr}(\mathrm{Al}) \mathrm{N}$ coatings: Mechanical and tribological study, Sufr. Coat. Tech., 200 (2005) 1-4, 192-197, doi.org/10.1016/j.surfcoat. 2005.02.105

${ }^{21}$ H. Jin, D. Y. Li, C. A. Guo, Study on mechanical property and microstructure of CrAlN coatings on PCrNi3Mo steel deposited by magnetron sputtering, Foundry Technology, 36 (2015) 6, 1467-1470, doi: $10.16410 /$ j.issn1000-8365.2015.06.042

${ }^{22}$ U. C. Oh, J. H. Je, Effects of strain energy on the preferred orientation of TiN thin films, J. Appl. Phys., 74 (1993) 3, 1692-1696, doi:10.1063/1.355297

${ }^{23}$ L. Chekour, C. Nouveau, A. Chala, Growth mechanism for chromium nitride films deposited by magnetron and triode sputtering methods, Sufr. Coat. Tech., 200 (2005) 1-4, 241-244, doi:10.1016/ j.surfcoat.2005.02.062

${ }^{24}$ H. W. Chen, Y. C. Chan, J. W. Lee, Oxidation resistance of nanocomposite CrAlSiN under long-time heat treatment, Sufr. Coat. Tech., 206 (2011) 7, 1571-1576, doi:10.1016/j.surfcoat.2011. 06.009

${ }^{25}$ S. Veprek, M. G. J. Veprek-Heijman, P. Karvankova, Different approaches to superhard coatings and nanocomposites, Thin Solid Films, 476 (2005) 1, 1-29, doi:10.1016/j.tsf.2004.10.053

${ }^{26}$ C. A. Guo, J. Zhang, Q. P. Guo, Performance of arc ion plated NiCoCrAlY coating on gun steel, Foundry, 62 (2013) 5, 365-368

${ }^{27}$ L. Cáceres, T. Vargas, L. Herrera, Influence of pitting and iron oxide formation during corrosion of carbon steel in unbuffered $\mathrm{NaCl}$ solutions, Corrosion Science, 51 (2009) 5, 971-978, doi:10.1016/ j.corsci.2009.02.021 